\title{
Bovine gene polymorphisms related to fat deposition and meat tenderness
}

\author{
Marina R.S. Fortes ${ }^{1}$, Rogério A. Curi ${ }^{2}$, Luis Artur L. Chardulo ${ }^{3}$, Antonio C. Silveira ${ }^{2}$, \\ Mayra E.O.D. Assumpção ${ }^{1}$, José Antonio Visintin ${ }^{1}$ and Henrique N. de Oliveira ${ }^{2}$ \\ ${ }^{1}$ Departamento de Reprodução Animal, Faculdade de Medicina Veterinária e Zootecnia, \\ Universidade de São Paulo, São Paulo, SP, Brazil. \\ ${ }^{2}$ Departamento de Melhoramento e Nutrição Animal, Faculdade de Medicina Veterinária e Zootecnia, \\ Universidade Estadual Paulista "Júlio de Mesquita Filho", Botucatu, SP, Brazil. \\ ${ }^{3}$ Departamento de Química e Bioquímica, Instituto de Biociências, \\ Universidade Estadual Paulista "Júlio de Mesquita Filho", Botucatu, SP, Brazil.
}

\begin{abstract}
Leptin, thyroglobulin and diacylglycerol O-acyltransferase play important roles in fat metabolism. Fat deposition has an influence on meat quality and consumers' choice. The aim of this study was to determine allele and genotype frequencies of polymorphisms of the bovine genes, which encode leptin (LEP), thyroglobulin (TG) and diacylglycerol O-acyltransferase (DGAT1). A further objective was to establish the effects of these polymorphisms on meat characteristics. We genotyped 147 animals belonging to the Nelore (Bos indicus), Canchim (5/8 Bos taurus $+3 / 8$ Bos indicus), Rubia Gallega X Nelore (1/2 Bos taurus + 1/2 Bos indicus), Brangus Three-way cross (9/16 Bos taurus + 7/16 Bos indicus) and Braunvieh Three-way cross (3/4 Bos taurus + 1/4 Bos indicus) breeds. Backfat thickness, total lipids, marbling score, ribeye area and shear force were fitted, using the General Linear Model (GLM) procedure of the SAS software. The least square means of genotypes and genetic groups were compared using Tukey's test. Allele frequencies vary among the genetic groups, depending on Bos indicus versus Bos taurus influence. The $L E P$ polymorphism segregates in pure Bos indicus Nelore animals, which is a new finding. The $T$ allele of $T G$ is fixed in Nelore, and DGAT1 segregates in all groups, but the frequency of allele $A$ is lower in Nelore animals. The results showed no association between the genotypes and traits studied, but a genetic group effect on these traits was found. So, the genetic background remains relevant for fat deposition and meat tenderness, but the gene markers developed for Bos taurus may be insufficient for Bos indicus.
\end{abstract}

Key words: bovine gene polymorphisms, candidate gene, fat deposition, beef cattle.

Received: September 14, 2007; Accepted: July 25, 2008.

\section{Introduction}

Fat deposition demands beef industry attention for many reasons. To name a few, lean to fat deposition ratio improvement means better feed conversion efficiency, less husbandry cost and lower pressure on world feed supplies (Sillence, 2004). The marbling aspect associates with intramuscular fat deposition, interfering with consumer habits and meat pricing (Killinger et al., 2004). Controlling backfat deposition is important because carcass quality and backfat thickness measurements are strongly associated with percentage of retail product. The weight of retail cuts, a trait of economic importance, is related to the ribeye area (Tait et al., 2005). Last but not least, fat deposition, espe-

Send correspondence to Marina Rufino Salinas Fortes. Faculdade de Medicina Veterinária e Zootecnia, Departamento de Reprodução Animal, Universidade de São Paulo, Av. Prof. Dr. Orlando Marques de Paiva 87, 05508-000 São Paulo, SP, Brazil. E-mail: marinafortes@usp.br. cially intramuscular fat, can interfere with meat tenderness perception (Crouse et al., 1989).

The LEP gene encodes leptin, a 16-kDa protein produced by adipocytes and implicated in food intake regulation, energy balance, reproduction efficiency and fat deposition (Houseknecht et al., 1998). Additionally, serum leptin has been correlated with fat deposition traits in cattle (Geary et al., 2003), and LEP is likely associated to the $B M 1500$ microsatellite, which is implicated in fat content of beef carcasses (Fitzsimmons et al., 1998). After Stone et al. (1996) mapped LEP to chromosome 4, many polymorphisms were described and associated with countless traits, from carcass fat content to fertility (Pomp et al., 1997; Buchanan et al., 2002; Barendse et al., 2005; Schenkel et al., 2005; Van Der Lende et al., 2005).

The $T G$ gene encodes thyroglobulin, the precursor of triiodothyronine and tetraiodothyronine, signals for fat cells development (Ailhaud et al., 1992; Darimont et al., 1993). Subcutaneous fat thickness and fat percentage of tis- 
sues in general, including milk, are expected to be influenced by $T G$ polymorphisms because the iodothyronines affect adipocyte differentiation and the thyroid hormone levels influence milk fat percentage (Folley and Malpress, 1948). Attempts to associate $T G$ markers and marbling or other fat deposition traits have been previously made, and $T G$ polymorphisms are included in commercial panels (Barendse, 1999; Barendse et al., 2004; Casas et al., 2005; Rincker et al., 2006; Van Eenennaam et al., 2007).

Many association studies support the diacylglycerol O-acyltransferase 1 gene (DGTA1) as a marker for fat deposition traits (Thaller et al., 2003; Kühn et al., 2004; Tantia et al., 2006). DGTAl encodes the catalyst enzyme of the reaction between diacylglycerol and acyl-CoA. This reaction is a final step in the synthesis of triglyceride, a major fat component. So, the enzyme encoded by DGTA1 regulates the rate of triglycerides in adipocytes (Coleman and Bell, 1976) and has been implicated in energy homeostasis (Havel, 2001). In addition, DGTA1 maps to chromosome 14 , where $T G$ is located, which is bodily related to the DNA marbling score marker CSSM66 (Barendse et al., 1997).

In spite of the support from the literature for selecting the candidate genes mentioned above, some conflicting reports show no association of these genes with fat deposition traits (Rincker et al., 2006). Also, most studies were conducted with Bos taurus cattle. Thus, the segregation and the predictive value of the $L E P, T G$, and DGAT1 polymorphisms for fat deposition and meat quality traits were yet to be analyzed in Bos indicus (Nelore breed and Nelore crossbreed cattle).

The objectives of the present study were to estimate the allele and genotype frequencies of single nucleotide polymorphisms (SNP) of the LEP, TG and DGAT1 genes and to associate genotypes with backfat thickness, total lipids (objective intramuscular fat deposition), marbling (subjective intramuscular fat deposition), ribeye area and shear force. The polymorphisms selected for the study were LEP/Kpn2I (Buchanan et al., 2002), TG/PsuI (Thaller et al., 2003) and DGAT1/CfrI (Winter et al., 2002).

\section{Material and Methods}

\section{Animals}

The study included carcasses of Nelore breed and of crosses that use Nelore as a formation breed, consisting on five different genetic groups. The genetic groups were classified as follows: 46 animals were Nelore - N - (Bos indicus $)$, 41 Canchim - C - (5/8 Bos taurus $+3 / 8$ Bos indicus), 19 Brangus Three-way cross - B3x - (9/16 Bos taurus $+7 / 16$ Bos indicus), and 15 Braunvieh Three-way cross - BV 3x - (3/4 Bos taurus + 1/4 Bos indicus). These animals were from the experimental feedlot facility of the $D e-$ partment of Genetics and Animal Nutrition - FMVZ, Botucatu, SP, Brazil. These cattle were sampled from four different farms, and the production system used in the uni- versity facility has been previously described in detail (Curi et al., 2005). Additional 26 Rubia Gallega X Nellore crossbred - RGxN - (1/2 Bos taurus $+1 / 2$ Bos indicus $)$ were sampled from a semi-intensive system. All animals were slaughtered within the age gap of 15 to 19 months.

After humanitarian slaughter, performed in a supportive abattoir, carcasses were identified and cooled for $24 \mathrm{~h}$, following which $2.50 \mathrm{~cm}$-thick samples/steaks were removed from the longissimus dorsi muscle, between the $12^{\text {th }}$ and the $13^{\text {th }}$ ribs. The ribeye area (REA), also referred to as longissimus dorsi area, was measured at the abattoir by the quadrant methodology described in the USDA Quality Grade (USDA, 1989). The steaks were vacuum-packaged and aged at 1 to $2{ }^{\circ} \mathrm{C}$ until 14 days postmortem and then frozen until the further analyses were carried out.

\section{Fat deposition and meat quality traits}

Further phenotypic analyses such as backfat thickness (BT), total lipids (TL), marbling score (MS), and shear force (SF) measurements were performed at the Chemistry and Biochemistry Department of the Institute of Biosciences of the São Paulo State University (UNESP, Botucatu, SP, Brazil), as described below.

Backfat thickness was measured with a caliper, following the methodology described in the USDA Quality Grade (USDA,1989). Marbling score was visually assessed (subjective scores from 1 to 5), according to the methodology described by the Aus-Meat Ltd (2001). Total lipids were evaluated using the method of Bligh and Dyer (1959). In short, six to eight cores of one inch $\mathrm{x}$ inch of meat were removed from the central area of each longissimus dorsi steak, carefully avoiding visible fat tissue. As mentioned above, the steaks used for this sampling were removed from the area between the $12^{\text {th }}$ and the $13^{\text {th }}$ ribs and were $2.54 \mathrm{~cm}$ thick. Then, the cores were minced and homogenized, before weighing the $5 \mathrm{~g}$ used for lipids assessment. Chloroform and methanol were added to the $5 \mathrm{~g}$ samples and rocked for over $30 \mathrm{~min}$, for lipid extraction. Then, the samples were centrifuged to separate three phases: hydrophilic (disposed), solid (disposed), and hydrophobic solution (used for volumetric measurements). Five milliliters of the hydrophobic phase were transferred to a previously weighed $50 \mathrm{~mL}$ beaker flask and let to dry overnight. The lipid content was calculated by the weight difference of the beaker. The lipid assessment of each animal was done in duplicate, and the final value is the mean of both results. Shear force was determined according to Wheeler et al. (1997), as follows. The frozen meat samples were thawed under refrigerated conditions $\left(4^{\circ} \mathrm{C}\right.$ for as long as $\left.24 \mathrm{~h}\right)$ until reaching an internal temperature of 5 to $6^{\circ} \mathrm{C}$, cooked until reaching an internal temperature of $71{ }^{\circ} \mathrm{C}$, cooled during $24 \mathrm{~h}$ at 5 to $6{ }^{\circ} \mathrm{C}$, and then cylindrical pieces of $1.27 \mathrm{~cm}$ in diameter were removed from each sample, parallel to muscle fiber orientation. The cores were cut in a Warner- 
Bratzler shear force measurement equipment (speed of $20 \mathrm{~cm} / \mathrm{min}$, with a $25 \mathrm{~kg}$ capacity).

\section{DNA extraction and genotyping}

After powdering meat samples with liquid nitrogen, DNA extraction was performed by digestion with protease $\mathrm{K}$ and precipitation with $\mathrm{NaCl}$ and alcohol, a non-phenolic method (Sambrook et al., 1989). After extraction, each DNA solution was checked for quantity and integrity by agarose gel electrophoresis, then diluted to work concentration $(10 \mathrm{ng} / \mu)$ and stored at $-20{ }^{\circ} \mathrm{C}$ until genotyping.

The animals were genotyped for the $L E P, T G$ and $D G A T 1$ genes by using the polymerase chain reaction - restriction length polymorphism (PCR-RFLP) technique. Alleles $C$ and $T$ of the $L E P$ gene were determined by the amplification of a $94 \mathrm{bp}$ fragment in exon 2, followed by digestion with Kpn2I, as reported by Buchanan et al. (2002). For the determination of alleles $C$ and $T$ of the $T G$ gene, a $548 \mathrm{bp}$ fragment located at the 5 ' untranslated region was amplified and digested with the $P s u \mathrm{I}$ restriction enzyme, as described by Thaller et al. (2003). Alleles $A$ and $K$ of the DGAT1 gene were identified by the amplification of a $411 \mathrm{bp}$ sequence corresponding to a fragment of exon 8 , followed by digestion with $C f r \mathrm{I}$, as reported by Lacorte $e t$ al. (2006).

After digestion of the amplified $L E P, T G$ and $D G A T 1$ gene products, the DNA fragments were separated, respectively, on 3.5, 2 and $2 \%$ agarose gels in a horizontal electrophoresis system. A standard molecular weight of $100 \mathrm{bp}$ was applied onto each gel, next to the amplified and digested DNA fragments, so their size could be estimated. Ethidium bromide staining and exposure to ultraviolet light were used to visualize the DNA fragments in the gel. Using a digital photo-documentation system, the gels were photographed for ulterior data analyses. Individual genotypes were determined for each polymorphism by analyzing the size (in bp) of the fragments.

\section{Statistical analysis}

Genotype and allele frequencies were calculated for each polymorphism according to Weir (1990). Differences in allele frequencies of the polymorphisms within and between genetic groups were determined by the method of Goodman adapted by Curi and Moraes (1981).

The traits of interest were analyzed by least square analysis of variance $(p=0.05)$, using the General Linear Model (GLM) procedure of the SAS program (SAS Institute Inc, 2004). The linear model used to fit the quantitative variables included, in addition to the genotype effect, the interaction between genetic groups and contemporary groups, as follows: Yijk $=\mu+\mathrm{G} i+\mathrm{GGC} j+\mathrm{e} i j k$, where Yijk $=$ production trait, $\mu=$ overall mean, $\mathrm{G} i=$ fixed effect of the $i^{\text {th }}$ genotype $(i=1, . ., 3), \mathrm{GGC} j=$ fixed effect of the $j^{\text {th }}$ genetic group and contemporary group combined $(j=1, \ldots$, 9 ), and eijk = random error. The criteria for the contempo- rary groups included variations of sex, age at slaughter, feedlot and farm of origin. Animals with the same age, feedlot and farm of origin were slaughtered on the same day. In other words, the interaction between genetic and contemporary groups resulted in 9 subgroups, as follow: Canchim FE, Canchim MF, Nelore MA, Nelore MB, Nelore MD, Rubia Galega x Nelore FC, Rubia Galega x Nelore MC, Brangus Three-way cross, and Braunvieh Three-way cross MF. In these subgroups, the first letter represents the sex of the animals $(F=$ female, $M=$ male $)$ and the second letter designates the day of slaughter $(\mathrm{A}, \ldots$, F). The least square means for genotypes and genetic subgroups were established and compared using the Tukey test. Genotypes with very low frequency (less than 0.10 ) in the total sample of individuals or genetic groups showing a single genotype were not included in the analysis, in order to prevent unreliable results. For the same reason, when most of the animals (over $80 \%$ ) of one genotype belonged to the same genetic group, this genotype was entirely excluded from the analyses. The sire effect was not included in the linear model because the number of genotyped animals which were progenies of the same sire was very small. So, the possibility of confounding the influence of the genotype effect and of the sire effect on production traits was low because of the large number of small half-sib families.

\section{Results}

The allele and genotype frequencies of all three polymorphisms in each genetic group and in the sample as a whole are summarized in Tables 1 and 2, respectively.

The two allelic forms of $L E P(C$ and $T)$ were observed in all five genetic groups. Two restriction fragments of 75 and $19 \mathrm{bp}$, respectively, were seen when the $C C$ genotype was present, and the TT genotype was reported from the observation of a $94 \mathrm{bp}$ fragment. Heterozygotes presented all three fragment sizes: 94, 75 and $19 \mathrm{bp}$. The genetic groups with higher Bos indicus influence (Nelore and Rubia Gallega $\mathrm{X}$ Nelore) presented a much lower frequency of allele $T$ (4.3 and $7.7 \%$, respectively) and no animal with genotype TT. The two Three-way crosses presented similar $T$ frequencies (20 to $26.3 \%$ ) and were different from the Canchim breed (39\%).

For $T G$, two allelic variants were reported: $C$ (295 and $178 \mathrm{bp}$ restriction fragments) and $T$ (intact PCR product $473 \mathrm{bp}$ fragment). $T G$ alleles $C$ and $T$ were segregating in most genetic groups, but allele $C$ was fixed in the Nelore animals, resulting in the occurrence of only the $C C$ genotype. Rubia Gallega X Nelore presented a very low frequency of $T(1.9 \%)$, with no statistically significant difference from the segregation of this polymorphism in the pure Nelore group. In fact, the occurrence of allele $T$ increased numerically with the higher Bos taurus influence on each genetic group: Brangus Three-way cross (15.8\%), Canchim (22\%), and Braunvieh Three-way cross (33.3\%). 
Table 1 - Allele frequencies of $L E P, T G$ and DGTA1 polymorphisms in five bovine genetic groups and in the sample as a whole.

\begin{tabular}{lccccccc}
\hline Polymorphism & Allele & \multicolumn{3}{c}{ Genetic group } & \multicolumn{2}{c}{ Total } \\
\cline { 3 - 6 } & & $\mathrm{N}(\mathrm{n}=46)$ & $\mathrm{RGxN}(\mathrm{n}=26)$ & $\mathrm{C}(\mathrm{N}=41)$ & $\mathrm{B} 3 \mathrm{x}(\mathrm{n}=19)$ & $\mathrm{BV} 3 \mathrm{x}(\mathrm{n}=15)$ \\
\hline LEP/Kpn2I & $C$ & $0.957^{\mathrm{A} ; \mathrm{a}}$ & $0.923^{\mathrm{A} ; \mathrm{a}}$ & $0.610^{\mathrm{B} ; \mathrm{ab}}$ & $0.737^{\mathrm{AB} ; \mathrm{a}}$ & $0.800^{\mathrm{AB} ; \mathrm{a}}$ & 0.810 \\
& $T$ & $0.043^{\mathrm{B} ; \mathrm{b}}$ & $0.077^{\mathrm{B} ; \mathrm{b}}$ & $0.390^{\mathrm{A} ; \mathrm{ab}}$ & $0.263^{\mathrm{AB} ; \mathrm{b}}$ & $0.200^{\mathrm{AB} ; \mathrm{b}}$ & 0.190 \\
\hline TG/PsuI & $C$ & $1.000^{\mathrm{A} ; \mathrm{a}}$ & $0.981^{\mathrm{A} ; \mathrm{a}}$ & $0.780^{\mathrm{B} ; \mathrm{a}}$ & $0.842^{\mathrm{AB} ; \mathrm{a}}$ & $0.667^{\mathrm{B} ; \mathrm{ab}}$ & 0.881 \\
& $T$ & $0.000^{\mathrm{B} ; \mathrm{b}}$ & $0.019^{\mathrm{B} ; \mathrm{b}}$ & $0.220^{\mathrm{A} ; \mathrm{b}}$ & $0.158^{\mathrm{AB} ; \mathrm{b}}$ & $0.333^{\mathrm{A} ; \mathrm{ab}}$ & 0.119 \\
\hline DGATI/Cfrl & $K$ & $0.946^{\mathrm{A} ; \mathrm{a}}$ & $0.462^{\mathrm{B} ; \mathrm{ab}}$ & $0.329^{\mathrm{B} ; \mathrm{b}}$ & $0.474^{\mathrm{B} ; \mathrm{ab}}$ & $0.367^{\mathrm{B} ; \mathrm{ab}}$ & 0.568 \\
& $A$ & $0.054^{\mathrm{B} ; \mathrm{b}}$ & $0.538^{\mathrm{A} ; \mathrm{ab}}$ & $0.671^{\mathrm{A} ; \mathrm{a}}$ & $0.526^{\mathrm{A} ; \mathrm{ab}}$ & $0.633^{\mathrm{A} ; \mathrm{ab}}$ & 0.432 \\
\hline
\end{tabular}

$\mathrm{N}=$ Nelore; RGxN = Rubia Gallega X Nelore; $\mathrm{C}=$ Canchim; $\mathrm{B} 3 \mathrm{x}=$ Brangus Three-way cross; BV3x = Braunvieh Three-way cross.

$\mathrm{A}, \mathrm{B}=$ Different allele frequencies between genetic groups $(\mathrm{p}<0.05)$.

$\mathrm{a}, \mathrm{b}=$ Different allele frequencies within genetic groups $(\mathrm{p}<0.05)$.

Table 2 - Genotype frequencies of the $L E P, T G$ and $D G T A 1$ gene polymorphisms obtained for five genetic groups and in the sample as a whole.

\begin{tabular}{|c|c|c|c|c|c|c|c|}
\hline \multirow[t]{2}{*}{ Polymorphism } & \multirow[t]{2}{*}{ Genotype } & \multicolumn{5}{|c|}{ Genetic group } & \multirow[t]{2}{*}{ Total } \\
\hline & & $N(n=46)$ & $\mathrm{RGxN}(\mathrm{n}=26)$ & $\mathrm{C}(\mathrm{N}=41)$ & B3x $(n=19)$ & BV $3 x(N=15)$ & \\
\hline \multirow[t]{3}{*}{$L E P / K p n 2 \mathrm{I}$} & $C C$ & 0.913 & 0.846 & 0.415 & 0.526 & 0.667 & 0.687 \\
\hline & $C T$ & 0.087 & 0.154 & 0.390 & 0.421 & 0.267 & 0.245 \\
\hline & $T T$ & 0.000 & 0.000 & 0.195 & 0.053 & 0.067 & 0.068 \\
\hline \multirow[t]{3}{*}{$T G / P s u \mathrm{I}$} & $C C$ & 1.000 & 0.962 & 0.610 & 0.648 & 0.467 & 0.789 \\
\hline & $C T$ & 0.000 & 0.038 & 0.341 & 0.316 & 0.400 & 0.184 \\
\hline & $T T$ & 0.000 & 0.000 & 0.049 & 0.000 & 0.133 & 0.027 \\
\hline \multirow[t]{3}{*}{$D G A T 1 / C f r 1$} & $K K$ & 0.913 & 0.077 & 0.073 & 0.067 & 0.158 & 0.347 \\
\hline & $K A$ & 0.065 & 0.769 & 0.512 & 0.632 & 0.600 & 0.442 \\
\hline & $A A$ & 0.022 & 0.154 & 0.415 & 0.211 & 0.333 & 0.211 \\
\hline
\end{tabular}

$\mathrm{N}=$ Nelore; $\mathrm{RGxN}=$ Rubia Gallega $\mathrm{X}$ Nelore; $\mathrm{C}=$ Canchim; $\mathrm{B} 3 \mathrm{x}=$ Brangus Three-way cross; BV3x = Braunvieh Three-way cross.

The DGAT1 alleles $(K$ and $A$ ) segregated in all genetic groups. When only allele $K$ was present, the fragment identified was like the intact PCR product, with $411 \mathrm{pb}$ in size. When only the alanine-bearing allele was present, two fragments were observed (208 and $203 \mathrm{pb}$, respectively). Heterozygous individuals were determined by the presence of fragments of three sizes: 411, 208 and 203 bp, respectively. In contrast, allele $A$ was less frequent in the Nelore breed, with a presence of only $5.4 \%$, compared to a range of 53 to $67 \%$ in the other four genetic groups.

The least square means and standard errors of quantitative meat traits for the different subgroups are shown in Table 3. A subgroup effect was found for all meat traits: backfat thickness $(p=0.0022)$, total lipids $(p=0.0002)$, ribeye area $(p<0.0001)$, and shear force $(p<0.0001)$.

The least square means and standard errors of quantitative meat traits for the different genotypes of polymorphisms DGAT1/Cfrl TG/PsuI and LEP/Kpn2I are shown in Table 4. Genotypes $C C$ and $C T$ were analyzed for an association with $L E P / K p n 2 \mathrm{I}$, but no significance was found for any of the traits: backfat thickness $(\mathrm{p}=0.1038)$, total lipids $(p=0.6298)$, ribeye area $(p=0.3355)$ and shear force
( $\mathrm{p}=0.9189$ ). To characterize the effects of $T G / P s u \mathrm{I}$, genotypes $C C$ and $C T$ were tested. No effect was found for $T G / P s u$ I on backfat thickness $(\mathrm{p}=0.7101)$, total lipids $(\mathrm{p}=0.2813)$, ribeye area $(\mathrm{p}=0.8044)$ or shear force $(\mathrm{p}=0.4361)$. For the analysis of polymorphism $D G A T 1 / C f r 1$, only genotypes $A A$ and $A K$ were considered, and no significant effect was found regarding an association with backfat thickness $(\mathrm{p}=0.5244)$, total lipids $(\mathrm{p}=0.6293)$, ribeye area $(\mathrm{p}=0.8235)$ or shear force $(\mathrm{p}=0.2124)$.

The visual assessment of marbling revealed to be ineffective for the Nelore or Bos indicus crosses subgroups studied because of its very low variability, shown by the fact that most animals scored 1 and only few individuals scored 2. So, no association tests were made for this trait.

\section{Discussion}

In 1997, Pomp et al. (1997) found an RFLP marker in the $L E P$ gene using the enzyme Sau3AI that segregates in numerous Bos taurus breeds but was fixed in Brahman cattle (Bos indicus), which made segregation and association studies in this case impossible. Buchanan et al. (2002) used 
Table 3 - Least square means and standard errors of the meat traits for each genetic group and subgroup.

\begin{tabular}{|c|c|c|c|c|c|}
\hline \multirow[b]{2}{*}{ Genetic group } & \multirow[b]{2}{*}{ Subgroup } & \multicolumn{4}{|c|}{ Meat traits } \\
\hline & & $\mathrm{BT}(\mathrm{mm})$ & TL $(\%)$ & $\operatorname{REA}\left(\mathrm{cm}^{2}\right)$ & $\mathrm{SF}(\mathrm{kg})$ \\
\hline \multirow[t]{2}{*}{$\mathrm{C}$} & F E & $3.75 \pm 1.96^{\mathrm{AB}}$ & $0.02 \pm 0.009^{\mathrm{AB}}$ & $62.51 \pm 6.58^{\mathrm{C}}$ & $3.68 \pm 0.64^{\mathrm{BC}}$ \\
\hline & M F & $3.69 \pm 1.55^{\mathrm{AB}}$ & $0.02 \pm 0.014^{\mathrm{AB}}$ & $79.98 \pm 9.46^{\mathrm{A}}$ & $3.68 \pm 0.65^{\mathrm{BC}}$ \\
\hline \multirow[t]{3}{*}{$\mathrm{N}$} & M A & $4.55 \pm 0.9^{\mathrm{B}}$ & $0.01 \pm 0.003^{\mathrm{AB}}$ & $64.90 \pm 4.99^{\mathrm{C}}$ & $4.55 \pm 1.28^{\mathrm{B}}$ \\
\hline & M B & $4.60 \pm 1.42^{\mathrm{B}}$ & $0.01 \pm 0.003^{\mathrm{AB}}$ & $70.64 \pm 8.29^{\mathrm{BC}}$ & $5.59 \pm 1.03^{\mathrm{A}}$ \\
\hline & M D & $3.66 \pm 1.50^{\mathrm{AB}}$ & $0.02 \pm 0.011^{\mathrm{A}}$ & $65.33 \pm 7.18^{C}$ & $3.77 \pm 0.62^{\mathrm{BC}}$ \\
\hline \multirow[t]{2}{*}{$\mathrm{RGxN}$} & $\mathrm{FC}$ & $2.69 \pm 1.31^{\mathrm{AB}}$ & $0.01 \pm 0.005^{\mathrm{B}}$ & $61.69 \pm 9.59^{\mathrm{C}}$ & $3.57 \pm 0.73^{\mathrm{BC}}$ \\
\hline & M C & $2.25 \pm 0.63^{\mathrm{A}}$ & $0.01 \pm 0.004^{\mathrm{AB}}$ & $62.90 \pm 7.56^{\mathrm{C}}$ & $3.83 \pm 1.27^{\mathrm{BC}}$ \\
\hline B3x & M F & $4.13 \pm 1.44^{\mathrm{B}}$ & $0.02 \pm 0.015^{\mathrm{AB}}$ & $75.45 \pm 7.29^{\mathrm{AB}}$ & $2.98 \pm 0.40^{\mathrm{C}}$ \\
\hline BV3x & M F & $3.83 \pm 1.31^{\mathrm{AB}}$ & $0.02 \pm 0.012^{\mathrm{AB}}$ & $74.65 \pm 3.16^{\mathrm{AB}}$ & $3.21 \pm 0.46^{\mathrm{C}}$ \\
\hline
\end{tabular}

$\mathrm{BT}=$ backfat thickness; $\mathrm{TL}=$ total lipids; $\mathrm{REA}=$ ribeye area, $\mathrm{SF}=$ shear force; $\mathrm{N}=$ Nelore; $\mathrm{RGxN}=$ Rubia Gallega $\mathrm{X}$ Nelore; $\mathrm{C}=\mathrm{Canchim} ; \mathrm{B} 3 \mathrm{x}=\mathrm{Bran}-$ gus Three-way cross; $\mathrm{BV} 3 \mathrm{x}=$ Braunvieh Three-way cross. The subgroups relate to contemporary criteria. $\mathrm{F}=$ female, $\mathrm{M}=$ male. A,..., $\mathrm{F}$ : slaughter days. $\mathrm{A}, \mathrm{B}, \mathrm{C}=$ Differences among genetic subgroups within each meat trait $(\mathrm{p}<0.05)$.

Table 4 - Least square means and standard errors of the meat traits for genotypes $L E P / K p n 2 \mathrm{I}, T G / P s u \mathrm{I}$ and $D G A T 1 / C f r 1$

\begin{tabular}{lccccc}
\hline & & \multicolumn{4}{c}{ Meat traits } \\
\cline { 3 - 6 } Locus & Genotype & $\mathrm{BT}(\mathrm{cm})$ & $\mathrm{TL}$ & $\mathrm{REA}\left(\mathrm{cm}^{2}\right)$ & $\mathrm{SF}(\mathrm{kg})$ \\
\hline LEP/Kpn $2 \mathrm{I}$ & $C C$ & $3.42 \pm 1.50$ & $0.016 \pm 0.012$ & $67.61 \pm 9.72$ & $3.68 \pm 0.87$ \\
& $C T$ & $3.96 \pm 1.60$ & $0.015 \pm 0.010$ & $69.20 \pm 9.09$ & $3.70 \pm 0.88$ \\
\hline TG/PsuI & $C C$ & $3.85 \pm 1.55$ & $0.021 \pm 0.011$ & $73.50 \pm 10.25$ & $3.41 \pm 0.53$ \\
& $C T$ & $4.00 \pm 1.63$ & $0.017 \pm 0.013$ & $73.05 \pm 8.25$ & $3.30 \pm 0.79$ \\
\hline \multirow{2}{*}{$D G A T 1 / C f r 1$} & $A A$ & $3.19 \pm 1.76$ & $0.017 \pm 0.012$ & $69.76 \pm 10.39$ & $3.64 \pm 0.75$ \\
& $A K$ & $3.43 \pm 1.46$ & $0.016 \pm 0.012$ & $70.19 \pm 10.69$ & $3.42 \pm 0.72$ \\
\hline
\end{tabular}

$\mathrm{BT}=$ backfat thickness; $\mathrm{TL}=$ total lipids; $\mathrm{REA}=$ ribeye area, $\mathrm{SF}=$ shear force.

the enzyme Kpn2I to assess a substitution of cytosine $(C)$ for thymine (T) at exon 2 of the $L E P$ gene (AF120500), assumed to cause an arginine to cysteine exchange, in Angus Hereford and Charolais breeds (Bos taurus). The overall allele frequency for the $L E P$ gene polymorphism reported by these authors was $54 \%(C)$ and $46 \%(T)$, figures that seemed different from the $81 \%(C)$ and $19 \%(T)$ frequencies found in the present study. A difference between Bos taurus animals and Bos indicus or Bos indicus crosses was actually expected. In fact, even within Bos taurus cattle the allele frequencies may be distinct in British (higher $T$ frequency) and in continental breeds (higher $C$ occurrence) (Buchanan et al., 2002).

Leptin polymorphisms have been associated with many characteristics of economic importance for livestock, including feed intake, milk yield, and carcass traits (Van der Lende et al., 2005). A study on Bos taurus (Angus, Charolais, Limousin and Simmental) found an association between two leptin exon 2 polymorphisms and lean yield (Schenkel et al., 2005). In Bos taurus animals, average fat and grade fat were shown to be affected by the genotype, and animals homozygous for allele $T$ produced more leptin
mRNA than those homozygous for allele $C$ (Buchanan et al., 2002), but no similar correlations with other fat deposition traits (backfat thickness and total lipids) were found in Bos indicus and Bos indicus crosses (present data). The results presented here are consistent with the association study that genotyped 3129 individuals, including many Bos taurus breeds and 317 Bos indicus (Brahman) animals, conducted by Barendse et al. (2005), who found no association between $L E P / K p n 2 \mathrm{I}$ and marbling, backfat thickness, intramuscular fat and adjusted total fat. In the present study, no correlation was found for REA and $L E P$, although Geary et al. (2003) found a negative correlation between the longissimus dorsi area and serum leptin, and moreover the serum concentrations of leptin were significantly associated with carcass composition (marbling, backfat thickness and kidney, pelvic and heart fat) and quality grade, in crossbred Bos taurus (1/2 Angus + 1/4 Charolais + 1/4 Tarentaise).

Polymorphism at the 5' untranslated region of the thyroglobulin $T G$ gene was patented by Barendse (1999) and is evaluated using $P s u$ I to distinguish alleles $C$ and $T$ (Thaller et al., 2003). The results obtained in the present 
study show allele $T$ to be less frequent than $C$. Similar figures - 22 to $25 \% T$ frequency - have been reported before for Bos taurus breeds (Thaller et al., 2003; Moore et al., 2003), and it is likely that the ranging for Canchim and both Three-way crosses is a little wider (15 to $33 \%$ ), due to the genetic influence of Nelore. A low $T$ frequency was expected for Bos indicus cattle (Casas et al., 2005), but this is the first record in Nelore, in which $C$ is fixed. Many previous studies have acknowledged TG/PsuI effects on: marbling (Barendse, 1999), backfat thickness and ribeye area (Casas et al., 2005), intramuscular fat (Thaller et al., 2003), and percent of retail cuts and carcass weight EPDs (Rincker et al., 2006). Moreover, Barendse et al. (2004) suggested that $T G / P s u$ I is a causative mutation within the marbling QTL and that $T$ is a favorable allele to intramuscular fat deposition. Yet, conflicting findings have been reported, and our results corroborate those which did not find any association between $T G$ polymorphism and marbling or tenderness score in Bos indicus Brahman cattle (Casas et al., 2005) or marbling, intramuscular fat, ribeye area and fat thickness in Bos taurus Simmental steers (Rincker et al., 2006), or even backfat EBV in Bos taurus (Moore et al., 2003). Thyroglobulin $C$ to $T$ variation is analyzed in the commercially available panel GeneSTAR Quality Grade (Genetic Solutions/Bovigen Pty. Ltd.), and the latest validation study confirmed the presence of allele $T$ in an increasing number of carcasses graded Choice or Prime, although marbling was not associated with the marker (Van Eenennaam et al., 2007). In the present study, the low frequency of the favorable allele made it difficult to establish an association of the polymorphism with carcass traits because of the small number of phenotypic data recorded for the TT genotype (only 4 animals).

Winter et al. (2002) discovered the DGAT1/CfrI polymorphism, which is a nonconservative substitution of two $G C$ nucleotides by $A A$ at positions 10433 and 10434 (AJ318490). This substitution imposes a protein substitution of lysine by alanine $(K 232 A)$, and these authors associated the lysine allele with higher milk fat content, suggesting the polymorphism as a causative mutation of the QTL for milk fat content. This original study observed that the $K$ variant was more common in Jersey animals (about $80 \%$ frequency), Holstein-Friesian and Anatolian Black animals (about 35\% frequency) than in other Bos taurus beef breeds (less than $20 \%$ of the lysine form). Previous studies on Bos indicus beef breeds found them to have the $K$ allele fixed (Winter et al., 2002; Tantia et al., 2006) or at very high frequency (Casas et al., 2005). Lacorte et al. (2006) reported that allele $K$ was fixed in Brazilian Bos indicus breeds (Nelore and Guzerat). The novelty presented by our findings was the low frequency $(5.4 \%)$ revealed for the occurrence of allele $A$ in pure Nelore animals. In this study, crossbreeds (Bos indicus X Bos taurus) presented a 33 to $48 \%$ frequency of allele $K$, a value that is intermediary between the figures found in the literature (Winter et al.,
2002; Moore et al., 2003) for Bos taurus beef breeds and the results found in this study for Bos indicus. The present findings, namely the lack of association between $K$ and higher marbling or higher total lipids, are not consistent with literature statements that consider DGAT1/CfrI to be the causative polymorphism for fat deposition traits (Grisart et al., 2004). However, a discrepancy about the effects of DGAT1 in cattle with different genetic backgrounds is already known, once it is significant for intramuscular fat content in German Holstein but not in Charolais animals (Thaller et al., 2003). Our results are in agreement with those of Casas et al. (2005), who found no association between $K 232 \mathrm{~A}$ alleles and backfat thickness, marbling, tenderness score or ribeye area in Brahman (Bos indicus) cattle. Kühn et al. (2004) reported a variable number of tandem repeats (VNTR) located upstream of DGAT1, which has an effect on milk fat content even among $A A$ individuals, further clarifying the BTA 14 QTL. It is possible that 5' VNTR DGAT1 contributes to fat deposition variability in Bos indicus animals.

According to Crouse et al. (1989), higher scores for tenderness are achieved in a sensory panel when intramuscular fat content is over 5\%. Previous reports showed association of $L E P$ with tenderness (Schenkel et al., 2005). Thus, the effect of LEP, TG and DGAT1 gene polymorphisms on shear force (mechanical evaluation of tenderness) was tested, but no association was found. Discrepancies among association studies may be related to different genetic backgrounds and variable epistatic effects and/or to environmental and management pressure on phenotypic data (Dekkers, 2004). The combined geneticenvironmental component, here represented by the subgroups, has an influence on all analyzed traits. Furthermore, comparing the results obtained for the subgroups for each analyzed trait, it seems that subgroups within the same breed type tend to share similar results. In contrast, subgroups from distinct breed types presented distinct results.

Hence, while the genetic (or breed type) effect on meat traits continues to be of importance, the gene markers, which underpin this effect, are yet to be discovered for Bos indicus-influenced cattle. In other words, the fixation (or very low frequency) of alleles in Bos indicus (Nelore) and the lack of additive value shown by the present results for these markers at LEP, TG and DGAT1 encourage a search for new markers. Adequate new marker panels should be developed specifically for Bos indicus cattle, to allow marker-assisted selection to be successful in Brazil.

\section{Acknowledgments}

The authors thank the Universidade Estadual Paulista "Júlio Mesquita Filho" (UNESP) for providing the infrastructure for this study and the Fundação de Ampara à Pesquisa do Estadoi de São Paulo (FAPESP) as well as the Conselho Nacional de Desenvolvimento Científico e Tecnológico $(\mathrm{CNPq})$ for financial support. 


\section{References}

Ailhaud G, Grimaldi P and Negrel R (1992) Cellular and molecular aspects of adipose tissue development. Annu Rev Nutr 12:207-233.

Aus-meat Limited (2001) International Red Meat Manual. Ausmeat Limeted, Brisbane, $111 \mathrm{pp}$.

Barendse WJ (1999) Assessing lipid metabolism. Int Pat Appl WO99/23248. World International Property Organization, Geneva.

Barendse W, Vaiman D, Kemp SJ, Sugimoto Y, Armitage SM, Williams JL, Sun HS, Eggen A, Agaba M, Aleyasin SA et al. (1997) A medium-density genetic linkage map of the bovine genome. Mamm Genome 8:21-28.

Barendse WJ, Bunch R, Thomas M, Armitage S, Baud S and Donaldson N (2004) The TG5 thyroglobulin gene test for a marbling quantitative trait loci evaluated in feedlot cattle. Austr J Exp Agricult 44:669-674.

Barendse WJ, Bunch RJ and Harrison BE (2005) The leptin C73T missense mutation is not associated with marbling and fatness traits in a large gene mapping experiment in Australian cattle. Anim Genet 36:71-93.

Bligh EG and Dyer WJ (1959) A rapid method of total lipid extraction and purification. Can J Biochem Physiol 37:911917.

Buchanan FC, Fitzsimmons CJ, Van Kessel AG, Thue TD, Winkelman-Sim DC and Schmutz SM (2002) Association of a missense mutation in the bovine leptin gene with carcass fat content and leptin mRNA levels. Genet Sel Evol 34:105116.

Casas E, White SN, Riley DG, Smith TPL, Brenneman RA, Olson TA, Johnson DD, Coleman SW, Bennett GL and Chase Jr CC (2005) Assessment of single nucleotide polymorphisms in genes residing on chromosomes 14 and 29 for association with carcass composition traits in Bos indicus cattle. J Anim Sci 83:13-19.

Coleman R and Bell RM (1976) Triacylglycerol synthesis in isolated fat cells. Studies on the microsomal diacylglycerol acyltransferase. J Biol Chem 251:4537-4543.

Crouse JD, Cundiff LV, Koch RM, Koomaraie M and Seidman SC (1989) Comparisons of Bos indicus and Bos taurus inheritance for carcass beef characteristics and meat palatability. J Anim Sci 67:2661-2668.

Curi PR and Moraes RV (1981) Associação, homogeneidade e contrastes entre proporções em tabelas contendo distribuições multinomiais. Cienc Cult 33:712-722.

Curi RA, Oliveira HN, Gimenes MA, Silveira AC and Lopes CR (2005) Effects of CSN3 and LGB gene polymorphisms on production traits in beef cattle. Genet Mol Biol 28:262-266.

Darimont C, Gaillard D, Ailhaud G and Negrel R (1993) Terminal differentiation of mouse preadipocyte cells: Adipogenic and antimitogenic role of triiodothyronine. Mol Cell Endocrinol 98:67-73.

Dekkers JCM (2004) Commercial application of markers and gene-assisted selection in livestock: Strategies and lessons. J Anim Sci 82:313-328.

Fitzsimmons CJ, Schmutz SM, Bergen RD and McKinnon JJ (1998) A potential association between the BM 1500 microsatellite and fat deposition in beef cattle. Mamm Genome 9:432-434.

Folley SJ and Malpress FH (1948) Hormonal control on mammary growth. In: Pincuss G and Thimamm KV (eds) The
Hormones. 1st edition. Academic Press, New York, pp 695-743.

Geary TW, McFadin EL, Macneil MD, Grings EE, Short RE, Funston RN and Keisler DH (2003) Leptin as a predictor of carcass composition in beef cattle. J Anim Sci 81:1-8.

Grisart B, Farnir F, Karim L, Cambisano N, Kim J-J, Kvasz A, Mni M, Simon P, Frère J-M, Coppieters W and Georges M (2004) Genetic and functional confirmation of the causality of the DGAT1 K232A quantitative trait nucleotide in affecting milk yield and composition. Proc Natl Acad Sci USA 101:2398-2403.

Havel PJ (2001) Peripheral signals conveying metabolic information to the brain: Short-term and long-term regulation of food intake and energy homeostasis. Exp Biol Med 226:963-977.

Houseknecht KL, Baile CA, Matteri RL and Spurlock ME (1998) The biology of leptin: A review. J Anim Sci 76:1405-1420.

Killinger KM, Calkins CR, Umberger WJ, Feuz DM and Eskridge KM (2004) Consumer visual preference and value for beef steaks differing in marbling level and color. J Anim Sci 82:3288-3293.

Kühn C, Thaller G, Winter A, Bininda-Emonds ORP, Kaupe B, Erhardt G, Bennewitz J, Schwerin M and Fries R (2004) Evidence for multiple alleles at the DGAT1 locus better explains a quantitative trait locus with major effect on milk fat content in cattle. Genetics 167:1873-1881.

Lacorte GA, Machado MA, Martinez ML, Campos AL, Maciel RP, Verneque RS, Teodoro RL, Peixoto MGCD, Carvalho MRS and Fonseca CG (2006) DGAT1 K232A polymorphism in Brazilian cattle breeds. Genet Mol Res 5:475-482.

Moore SS, Li C, Basarab J, Snelling WM, Kneeland J, Murdoch B, Hansen C and Benkel B (2003) Fine mapping of quantitative trait loci and assessment of positional candidate genes for backfat on bovine chromosome 14 in a commercial line of Bos taurus. J Anim Sci 81:1919-1925.

Pomp D, Zou T, Clutter AC and Barendse W (1997) Rapid communication: Mapping of leptin to bovine chromosome 4 by linkage analysis of a PCR-based polymorphism. J Anim Sci 75:1427.

Rincker CB, Pyatt NA, Berger LL and Faulkner DB (2006) Relationship among GeneSTAR marbling marker, intramuscular fat deposition and expected progeny differences in early weaned Simmental steers. J Anim Sci 84:686-693.

Sambrook J, Fritsch EF and Maniatis T (1989) Molecular Cloning: A Laboratory Manual. Cold Spring Harbor Laboratory Press, New York, 540 pp.

SAS Institute Inc. (2004). SAS/STAT User's Guide, v. 9.1. SAS Institute Inc, Cary.

Schenkel FS, Miller SP, Ye X, Moore SS, Nkrumah JD, Li C, Yu J, Mandell IB, Wilton JW and Williams JL (2005) Association of single nucleotide polymorphisms in the leptin gene with carcass and meat quality traits of beef cattle. J Anim Sci 83:2009-20.

Sillence MN (2004) Technologies for the control of fat and lean deposition in livestock. Vet J 167:242-257.

Stone RT, Kappes SM and Beattie CW (1996) The bovine homologue of the obese gene maps to chromosome 4 . Mamm Genome 7:399-400.

Tait JRRG, Wilson DE and Rouse GH (2005) Prediction of retail product and trimmable fat yields from the four primal cuts in 
beef cattle using ultrasound or carcass data. J Anim Sci $83: 1353-1360$

Tantia MS, Vijh RK, Mishra BP, Mishra B, Bharani Kumar ST and Sodhi M (2006) DGAT1 and $A B C G 2$ polymorphism in Indian cattle (Bos indicus) and buffalo (Bubalus bubalis) breeds. Bio-Med Central Vet Res 2:e32.

Thaller G, Kuhn C, Winter A, Ewald G, Bellmann O, Wegner J, Zuhlke H and Fries R (2003) DGAT1, a new positional and functional candidate gene for intramuscular fat deposition in cattle. Anim Genet 34:354-357.

USDA (1989) United States Standards for Grades of Carcass Beef. Agric Marketing Service, Washington DC.

Van Der Lende T, Te Pas MF, Veerkamp RF and Leifers SC (2005) Leptin gene polymorphisms and their phenotypic associations. Vitam Horm 71:373-404.

Van Eenennaam AL, Li J, Thallaman RM, Quaas RL, Dikeman ME, Gill CA, Franke DE and Thomas MG (2007) Valida- tion of commercial DNA tests for quantitative beef quality traits. J Anim Sci 85:891-900.

Weir BS (1990) Genetic data analysis: Methods for discrete population genetic data. Sinauer Associates, Massachusetts, $377 \mathrm{pp}$.

Wheeler TL, Shakelford SD, Johnson LP, Miller MF, Miller RK and Koohmaraie M (1997) A comparison of WarnerBratzler shear force assessment within and among institutions. J Anim Sci 75:2423-2432.

Winter A, Kramer W, Werner FA, Kollers S, Kata S, Durstewitz G, Buitkamp J, Womack JE, Thaller G and Fries R (2002) Association of a lysine-232/alanine polymorphism in a bovine gene encoding acyl-CoA: Diacylglycerol acyltransferase (DGAT1) with variation at a quantitative trait locus for milk fat content. Proc Natl Acad Sci USA 99:9300-9305.

Associate Editor: Luiz Lehmann Coutinho

License information: This is an open-access article distributed under the terms of the Creative Commons Attribution License, which permits unrestricted use, distribution, and reproduction in any medium, provided the original work is properly cited. 